\title{
PEMBERDAYAAN EKONOMI MASYARAKAT TIRTONIRMOLO DI TENGAH PANDEMIK COVID-19
}

\author{
Eko Nursubiyantoro'), Astrid Wahyu Adventri Wibowo' ${ }^{1)}$, Ismianti ${ }^{1)}$ \\ ${ }^{1)}$ Jurusan Teknik Industri, UPN Veteran Yogyakarta, Indonesia. \\ E-mail address eko_nsby072@upnyk.ac.id, E-mail address astrid.wahyu@upnyk.ac.id, \\ E-mail address ismianti@upnyk.ac.id
}

\begin{abstract}
Tirtonirmolo is one of the villages from Kasihan District whose routine activities are administrative services, which are supported by Bumdes so that the economic activities of the community grow and make a positive stretch for the village economy and the welfare of the community. Such dynamic economic and governmental activities at this time suddenly seem to stop, there is no activity as usual, because of the corona virus outbreak which has changed the structure of society, both government services and the economic movement of the community. The problem of the Tirtonirmolo Village Government is that it must continue to carry out government service duties and encourage community empowerment to continue to carry out economic activities, with the guarantee that the implementation of government services and economic activities must run safely. The service activity method is to design a service information system based on the needs of the village government, design an automatic disinfectant tool to meet protocols, design a social distancing-based work environment, empower the economy by providing training in the application of information systems for products and services online so that the economy of the Tirtonirmolo community will recover as before. there was a Covid19 outbreak. The expected output target is to restore a clean and healthy working environment and an ever increasing economic movement.
\end{abstract}

Keywords: services, implementation of health protocols, economic empowerment

\begin{abstract}
Abstrak
Tirtonirmolo adalah salah satu Desa dari Kecamatan Kasihan yang aktifitas kegiatan rutinnya adalah pelayanan administrasi, yang didukung oleh Bumdes sehingga kegiatan ekonomi masyarakat tumbuh dan menjadikan geliat yang positif bagi ekonomi desa dan kesejahteraan masyarakatnya. Kegiatan ekonomi dan pemerintahan yang begitu dinamis tersebut pada saat ini tiba-tiba seolah berhenti, tidak ada aktivitas seperti biasanya, karena adanya wabah virus corona yang merubah tatanan warga masyarakat, baik layanan pemerintahan maupun gerak ekonomi masyarakat. Permasalahan Pemerintah Desa Tirtonirmolo adalah harus tetap melaksanakan tugas pelayanan pemerintahan serta mendorong pemberdayaan masyarakat untuk tetap melaksanakan aktifitas ekonominya, dengan jaminan
\end{abstract}


pelaksanaan layanan pemerintahan dan aktifitas ekonomi harus berjalan dengan aman. Metode kegiatan pengabdian adalah merancang sistem informasi layanan berdasarkan kebutuhan pemerintah desa, merancang alat disenfektan automatis untuk memenuhi protokol, merancang lingkungan kerja berbasis social distancing, memberdayakan ekonomi dengan memverikan pelatihan aplikasi sistem informasi produk dan jasa secara daring agar gerak ekonomi masyarakat Tirtonirmolo kembali pulih seperti sebelum terjadi wabah Covid-19. Target luaran yang diharapkan adalah mengembalikan kondisi lingkungan kerja yang bersih dan sehat, serta gerak perekonomian yang semakin meningkat.

Kata kunci: pelayanan, penerapan protokol kesehatan, pemberdayaan ekonomi.

\section{PENDAHULUAN}

Kalurahan Tirtonirmolo adalah salah satu dari 4 Kalurahan di Kecamatan Kasihan, dengan 12 pedukuhan dan jumlah wilayah 107 RT. Jumlah penduduk kalurahan Tirtonirmolo total tercatat pada tahun 2019 adalah sebesar 25.152 jiwa, terdiri dari 12.582 laki-laki dan 12.570 perempuan (Lurah Desa Tirtonirmolo, 2019). Sebanyak 361 penduduk kelurahan Tirtonirmolo bekerja pada bidang pertanian dan perkebunan. Mata pencaharian di bidang pertanian dan perkebunan tersebut sekaligus menjadi pekerjaan yang paling banyak dilakoni oleh warga Tirtonirmolo. Kalurahan Tirtonirmolo termasuk daerah pinggiran perkotaan, dengan aktivitas kegiatan pelayanan administrasi yang termasuk ramai, karena mobilitas keperluan masyarakat yang cukup kompleks. Tirtonirmolo juga memiliki BUMDES yang diberi nama Usaha Ekonomi Desa (UED) Sedyo Makmur, untuk mendukung usaha-usaha ekonomi warga masyarakat agar dapat memperoleh pembiayaan dengan prosedur yang mudah. Desa Tirtonirmolo juga ditempati Pasar Tradisional Kabupaten Bantul yaitu Pasar Niten, memiliki pusat kuliner dan oleh-oleh, serta taman bermain dan ruang pamer. Kegiatan ekonomi masyarakat Tirtonirmolo yang tumbuh berkembang pesat, mulai dari sektor pariwisata agro PG Madukismo, situs budaya dan jajanan kuliner yang khas menjadikan geliat yang positif bagi kemajuan ekonomi desa dan kesejahteraan masyarakatnya (Lurah Desa Tirtonirmolo, 2019). Gambaran umum tentang geliat kegiatan ekonomi dan pemerintahan yang begitu dinamis pada saat ini seolah-olah berhenti, tidak ada aktivitas kegiatan yang seperti biasanya. Hal ini karena kita semua di kejutkan dengan adanya wabah virus corona yang bermula dari Wuhan China. Virus yang diduga terus menyebar ke berbagai negara, sehingga menyebabkan tingginya tingkat penularan dan akhirnya menyebabkan kematian (Buana, 2020). Virus corona ini tidak hanya mempengaruhi kesehatan, akan tetapi juga berdampak pada perekonomian global termasuk di Indonesia. Adanya virus itu menekan gerak perekonomian dan layanan pemerintahan secara umum di Indonesia. Sebelumnya seluruh lembaga internasional memprediksi tahun ini penuh dengan optimisme, namun hanya dalam sekejab setelah wabah ini mengemuka, proyeksi tersebut berbalik arah karena dahsyatnya wabah virus corona (Hackl \& Dibernet, 2019). Tatanan warga masyarakat menjadi berubah, baik layanan pemerintahan maupun gerak ekonomi masyarakat (KumparanBisnis, 2020). Tak terkecuali hal ini juga dialami oleh pemerintah desa 
dan warga masyarakat Tirtonirmolo, yang semua kita tidak tahu kapan hal ini akan berakhir. Dari hasil pengamatan dan diskusi-diskusi dengan pemerintah desa dan kelompok masyarakat pelaku ekonomi ditemukan beberapa persoalanpersoalan yang menjadi permasalahan dan belum dilakukan pemberdayaan secara optimal. Permasalahan yang ada adalah bagaimana menjalankan kegiatan pelayanan desa dengan aman serta memberdayakan warga masyarakat khususnya pelaku ekonomi dapat berjalan baik dan meningkatkan kemandirian ekonomi serta kesejahteraan. Tujuan dari kegiatan pengabdian ini adalah peningkatan kualitas dan kuantitas layanan pemerintahan, peningkatan pasar produk dan jasa, serta peningkatan kesadaran warga masyarakat akan dalam memasuki tatanan kehidupan baru.

\section{METODE DAN PELAKSANAAN}

\begin{abstract}
Kegiatan pengabdian dengan mengambil tema Peningkatan pemberdayaan ekonomi masyarakat melalui pemasaran produk dan jasa pada kondisi pandemik Covid-19 ini berprinsip pada pemberdayaan masyarakat (Kementrian Perindustriana, 2015), maka metode yang dipilih adalah metode yang mampu memberikan kesempatan kepada pemerintah dan masyarakat yang menjadi kelompok sasaran untuk mengungkapkan informasi dan aspirasi sehingga akan didapatkan informasi yang lengkap dan holistik (Kementerian Perindustrian, 2015).
\end{abstract}

\section{Metode}

Metode yang digunakan (Ginting, 2010) adalah (1) Merancang sistem informasi layanan berdasarkan kebutuhan pemerintah desa, (2) Merancang dan menerapkan alat disinfektan automatic, (3) Merancang lingkungan kerja berbasis social distancing, (4) merancang sistem informasi produk dan jasa secara daring.

\section{Pelaksanaan Kegiatan}

Kegiatan merancang sistem informasi layanan berdasarkan kebutuhan pemerintah desa ini dimaksudkan untuk membantu kegiatan layanan pemerintahan yang berbasis sistem informasi dan dilakukan secara daring, maksud dari rancangan ini adalah untuk meminimasi kontaks fisik antara warga masyarakat dan pemerintah desa. Perancangan sistem dilaksanakan di Desa Tirtonirmolo dengan melibatkan 3 orang staf Desa sebagai narasumber kebutuhan rancangan. Hasil rancangan adalah sistem informasi berbasis web yang digunakan untuk layanan pengurusan pengantar surat-surat kependudukan, dan layanan informasi tentang pelaporan kedatangan penduduk antar daerah. Sistem informasi yang telah dihasilkan dapat berguna bagi warga dusun dalam mengurus surat-surat kependudukan dengan tanpa harus kontak langsung dengan pamong desa, sehingga untuk tujuan kegiatan layanan pemerintahan dengan mengurangi penyebaran covid-19 tercapai. Kegiatan berikutnya adalah merancang dan membuat alat disinfektan automatic. Kegiatan ini dilaksanakan di Kantor Desa dengan melibatkan 3 staf desa, hal ini dimaksudkan untuk membuat alat teknologi tepat guna yang sederhana untuk sarana mensterilkan setiap orang yang akan memasuki kantor desa, terkait keharusan pengurusan administrasi pemerintahan yang terpaksa harus dilakukan secara luring. Hasil rancangan diterapkan pada halaman sebelum masuk pintu utama pelayanan pemerintahan, penerapan protokol kesehatan untuk memakai masker, mencuci tangan dengan sabun dapat dilaksanakan dengan baik. Khusus ruang penyemprotan ruang disenfektan untuk mencegah virus covid19 juga telah terpasang, hanya terdapat terdapat kendala penerapannya. Kendala tersebut terkait dengan pengoperasian 
dan seiring waktu pada saat ini telah sedikit dilonggarkan untuk penggunaan disenfektan, dan digunakan metode yang lainnya. Kegiatan merancang lingkungan kerja berbasis social distancing, melibatkan seluruh staf dan pamong desa, lokasinya adalah Kantor Desa. Perancangan ini penting karena bertujuan untuk menata tempat dan lingkungan kerja Pemerintah Desa Tirtonirmolo agar memenuhi protokol social distancing. Rancangan lingkungan kerja akan diterapkan dengan memperhatikan alur pekerjaan dan jarak yang sesuai dengan protokol social distancing. Rancangan ini berupa desain tata letak stasiun kerja pemerintahan Desa Tirtonirmolo untuk pelayanan administrasi pemerintahan dan kependudukan bagi warga masyarakat. Kegiatan merancang sistem informasi produk dan jasa secara daring ini dimaksudkan untuk membuat sistem informasi berupa web jual beli untuk mewadahi para pelaku ekonomi warga masyarakat Tirtonirmolo. Kegiatan pelatihan untuk warga masyarakat Desa Tirtonirmolo yang berbasis punya usaha rumahan untuk didorong lebih meningkatkan usahanya agar berkembang.

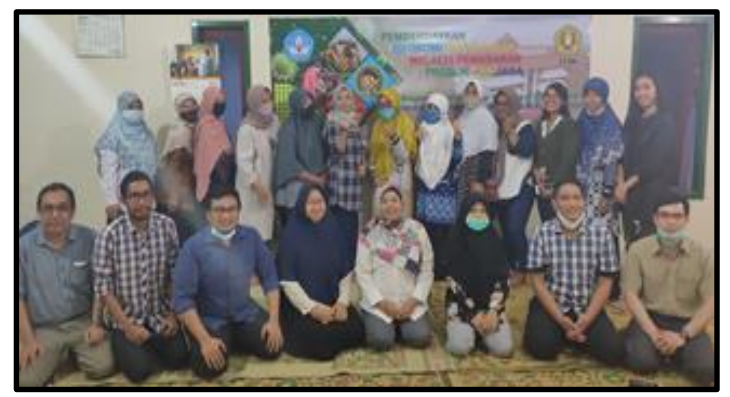

Gambar 1. Pelatihan pemasaran produk

Pelatihan dilaksanakan dengan pertemuan secara daring diikuti oleh sekitar 20-25 warga bertempat di Gedung Pertemuan Pedukuhan 4, untuk diberikan pemahaman bagaimana memasarkan produknya agar dibeli oleh konsumen, dipasarkan yang lebih meluas dan lebih dikenal oleh konsumen. Materi pelatihan meliputi bagaimana memasarkan produk secara daring melalui web, diantaranya cara-cara memanfaatkan gadget android untuk pemasaran digital melalui instagram, facebook, bukalapak, shopee. Kontinuitas ditempuh dengan cara membuka konsultasi setiap saat kepada peserta pelatihan agar bisa memahami materi yang diberikan pada saat pelatihan.

\section{HASIL DAN PEMBAHASAN}

Hasil dan luaran yang telah dicapai dalam proses pelaksanaan kegiatan Pengabdian kepada Masyarakat ( $\mathrm{PbM})$ untuk menyelesaikan permasalahan mitra, dalam rangka peningkatan dan pemberdayaan ekonomi masyarakat pada kondisi pandemik Covid-19 sesuai jadwal yang telah kami rencanakan. Aspek layanan pemerintahan kami telah membuat rancangan sistem informasi layanan pemerintahan, sistem ini dapat membantu kegiatan aktifitas pengurusan surat-surat yang terkait kebutuhan administrasi pemerintahan warga masyarakat Desa Tirtonirmolo dengan mengurangi kontak langsung antara pamong desa dan warga masyarakat. Pembuatan rancangan alat, sarana dan lingkungan kerja yang menerapkan protokol Covid-19, dapat diterapkan dengan baik dan dipatuhi oleh warga masyarakat, terutama saat pengurusan administrasi pemenrrintahan yang dilaksanakan harus secara daring. Aspek pemberdayaan ekonomi masyarakat telah berhasil memberdayakan warga masyarakat yang berbasis industri rumahan untuk dapat meningkatkan kegiatan pemasaran produk dan jasanya secara digital/daring, dengan memanfaatkan gadget android yang dimiliki oleh sebagian besar warga masyarakat. 


\section{PENUTUP}

Berdasarkan hasil program pengabdian pada masyarakat dengan skema program pemberdayaan ekonomi masyarakat Desa Tirtonirmolo, Kecamatan Kasihan, Kabupaten Bantul, DI Yogyakarta.

\section{Simpulan}

Bahwa dalam masa pandemi COVID-19 sebagai masa krisis, optimisme masih tetap berjalan. Program pengabdian yang direncanakan dan dibuat telah terealisasi, pelaku usaha dapat meningkatkan pendapatan melalui pemasaran produk secara daring, kegiatan pemerintahan desa yang berjalan baik dengan rancangan aplikasi pengurusan administrasi berbasis sistem informasi, penerapan desain lingkungan kerja dan interaksi luring dengan penerapan protokol kesehatan.

\section{Saran}

Program ini masih diperlukan pendampingan intensif melalui program $\mathrm{PbM}$ yang berkelanjutan, agar lebih baik dan sempurna.

\section{Ucapan Terima Kasih}

Program pengabdian pada masyarakat melalui $\mathrm{PbM}$ internal ini diselenggarakan dan didukung sepenuhnya oleh Lembaga Penelitan dan Pengabdian (LP2M) UPN "Veteran" Yogyakarta ini dengan pendanaan Tahun Anggaran 2020. Ucapan terimakasih yang kami ucapkan kepada LP2M UPN "Veteran" Yogyakarta, Pemerintah Desa Tirtonirmolo dan segenap warga masyarakat yang menjadi mitra.Penutup berisi simpulan dan saran yang masingmasing ditulis sebagai sub judul. Pada bagian ini kadang-kadang juga dimuat ucapan terimakasih.

\section{DAFTAR PUSTAKA}

Buana, D. R. (2020). Analisis Perilaku Masyarakat Indonesia dalam Menghadapi Pandemi Virus Corona (Covid-19) dan Kiat Menjaga Kesejahteraan Jiwa. SALAM: Jurnal Sosial Dan Budaya Syar-I, 7(3). https://doi.org/10.15408/sjsbs.v7i3 .15082

CNN Indonesia. (2020, Maret 14). Mengenal Social Distancing sebagai Cara Mencegah Corona. CNN Indonesia. https://www.cnnindonesia.com/ga yahidup/20200314102823-255483358/mengenal-socialdistancing-sebagai-caramencegahcorona., diakses 5 Juli 2020.

Daryono, B. S. (2020). Covid-19 Berakhir pada Kemarau? Jawa Pos, p. https://www.jawapos.com/opini/o 6/04/2020/covid-19, diakses 5 Juli 2020.

Ginting, R., 2010, Perancangan Produk. Graha Ilmu, Cetakan Pertama, Yogyakarta.

Hackl, J., \& Dubernet, T. (2019). Epidemic Spreading in Urban Areas Using Agent-Based Transportation Models. Future Internet, 1-14. https://doi.org/10.3390/fi1104009 2, diakses 5 Juli 2020.

Kementrian Perindustriana, (2015), Kontribusi UMKM Naik, http://www.kemenperin.go.id/ artikel/14002/Kontribusi-UMKM Naik, diakses 30 Juni 2020.

Kementrian Perindustrianb, (2015), Tangkal Krisis, Kadin Minta UMKM Diperkuat, http://kemenperin.go.id/artikel/76 84/Tangkal-Krisis,-Kadin-MintaPeran-UMKM-Diperkuat, diakses 30 Juni 2020.

KumparanBisnis.(2020, Januari 28). Sri Mulyani: Virus Corona Ancam 
Ekonomi Seluruh Dunia. Kumparan.

https://kumparan.com/kumparanb isnis/sri-mulyani-virus-coronaancam-ekonomi-seluruh-dunia1sjHMYpx9EG?utm_source=LINE \&utm_medium=Aggregator\&read_ meta $=$

\%7B\%22label\%22\%3A\%22articlepa ge_number2\%22\%2C\%22group $\% 2$ 2\%3A\%22\%22\%7D, diakses 5 Juli 2020.

Lembaga Penelitian dan Pengabdian Kepada Masyarakat UPN "Veteran" Yogyakarta, (2018), Panduan Pelaksanaan Pengabdian Bagi Masyarakat Internal (PbM) dan Standard Operational Procedure (SOP) Pengabdian Kepada Masyarakat, LPPM UPNVY Press, Yogyakarta.

Lurah Desa Tirtonirmolo. (2019). Laporan Pertanggungjawaban Pemerintah Desa Tirtonirmolo Tahun 2019, Desember 2019, Desa Tirtonirmolo, Yogyakarta.

Nurmianto, E., (2004), Ergonomi Konsep Dasar dan Aplikasinya, Cetakan Kedua, Prima Printing, Surabaya.

Nutranta, R., (2005), Forward Engineering Design Metode VDI 2221. Pusat pengembangan bahan ajar, Universitas Mercu Buana, Jakarta.

Santoso, (2013), Pengantar Perancangan Produk. Bandung , Institut Teknologi Bandung.Sujimat, D. A. 2000. Penulisan Karya Ilmiah. Makalah disampaikan pada Pelatihan Penelitian bagi Guru SLTP Negeri di Kabupaten Sidoarjo tanggal 19 Oktober 2000 (Tidak diterbitkan). MKKS SLTP Negeri Kabupaten Sidoarjo. 